\title{
Liberal Equality and the Moral Status of Parent-Child Relationships
}

\author{
Serena Olsaretti
}

\section{INTRODUCTION}

The family, and in particular the parent-child relationship that constitutes its core, is attracting increasing attention among political philosophers. Contemporary theorists of justice, who, until a couple of decades ago, either neglected the family or saw its relevance mostly in light of its being a site of gender injustice, are now addressing a host of questions about the structure and role of the family in a just society (Macleod 2002; Clayton 2006; Archard 2010a; Brighouse and Swift 2014).

One such question is whether and why in a just society there should be parent-child relationships (or the family) at all. Tackling it head on, a few liberal egalitarian philosophers now defend the family by appealing to the non-instrumental value of the parent-child relationship for both parents and children alike (Macleod 2002, 2010; Brighouse and Swift 2009, 2014). They claim that this defense of the family accounts for some of the prerogatives and responsibilities that are often seen to characterize the parent-child relationship, while at the same time showing others to be unwarranted. In particular, this "relationship view" aims to give support to parents' having rights over their children, including the right to exercise some discretion about how to raise them (compatibly with their respecting children's claims). It also aims to show that some parental partiality is justified-namely, the kind of partiality that is integral to the valuable parent-child relationship.

The relationship view thus addresses two challenges that the justification of the family raises for liberal egalitarians: the problem of authority and the problem of partiality. These two challenges point, respectively, to the burdens of justifying to children their parents' having rights over them, and to 
third parties parents' favoring of their children in ways that disrupt equality. This paper asks whether the relationship view succeeds in meeting these challenges. It suggests that it does not fully do that: the relationship view does not capture some important convictions about the moral status of the parent-child relationship and, as a result, it does not fully address the two stated challenges. The paper also offers an alternative basis for justifying the parent-child relationship on which parents, by virtue of being morally responsible for their children's existence, have an obligation to enter a relationship with them. Section 1 outlines the challenges of authority and of partiality in more detail. Sections 2 and 3 introduce the main claims of the relationship view, by contrasting it with those made by the instrumental view of the family, and identify its main shortcomings. Section 4 presents my alternative view, on which those who are morally responsible for a child's existence have an obligation to enter and sustain a caring relationship with that child.

\section{LIBERAL EGALITARIANISM AND THE BURDENS OF JUSTIFYING THE FAMILY}

In justifying the family, liberal egalitarians face two specific challenges- that of authority and of partiality_-reflecting their liberal and their egalitarian commitments.

The problem of authority is the problem of how to justify granting parents rights over children-rights which, compatibly with some of the children's interests being respected, are quite extensive, conferring on parents the authority to make many weighty decisions for their children. Providing such a justification raises a challenge for liberal egalitarians because, independently of whether they conceive of children as autonomous, liberal egalitarians recognize that children deserve equal moral consideration, so childrearing practices must be justifiable by appeal to children's interests (see Brennan and Noggle 1997; Macleod 2002; Vallentyne 2003). Moreover, since liberal egalitarians include amongst these interests the child's interest in her future autonomy, and, on some views, the child's interest in independence, any exercise of parental authority must be duly constrained, and subjected to the test of the future child's retroactive approval (Feinberg 1994; Clayton 2006).

The problem of authority, then, points to the burden of justification to children of their parents' having rights over them. This justification must achieve two things: first, it must show that the possession and exercise of authority over the child of the kind that characterizes parent-child relationships 
is legitimate; second, it must show that the exercise of authority over particular children by some particular adult(s) is legitimate. A full justification of the parent-child relationship must include both these elements: we need an account of both what may and should be done to and for children (what the caring role that some adults may and should play vis-à-vis children amounts to), and who may and should do certain things to and for children, and for which ones in particular (who should fulfill that role vis-à-vis which child). Since there is no reason to assume that the first question is normatively prior to, and sets the parameters for answering, the second, an account of the family that answered only the first of these questions would be incomplete in a troubling way. ${ }^{1}$

The second main challenge faced by liberal egalitarian defenses of the family, namely, that of partiality, points to the burden of justifying the family to third parties (other children, parents, and adults). This is the problem of partiality. Because of their egalitarian commitments, liberal egalitarians face the challenge of showing that the family is justified despite the fact that it realizes and creates inequalities that disadvantage others. The family realizes inequalities in the sense that the parent-child relationship that constitutes the family is itself an instantiation of unequal treatment. Adults who are parents, by parenting, favor their children over other children and adults: by raising and caring for some children rather than others, and insofar as they engage in parenting rather than in other third-parties-benefiting-activities, parents give their children valuable goods, i.e. their focused energies, affection, time, and attention, in a context in which it is highly likely, even under ideal conditions, that people's access to these goods is unequal. The family also creates inequalities, in that parents are disposed to promote their children's interests and to favor their children in ways other than by having a caring relationship with them (though as a result of their having that relationship), such as by investing their material resources on them. Thus the family has been seen by liberal egalitarians as a threat to equality of opportunity, and to the egalitarian commitments of liberal egalitarianism more generally, both under non-ideal and ideal conditions. ${ }^{2}$

${ }^{1}$ I return to this point in the next section, as this is one of the points of contention I have with both the instrumental and the relationship views of the parent-child relationship.

${ }^{2}$ For the classic statement of these worries, see Rawls 1971 and Fishkin 1983. For some more recent statements, see Macleod 2002, 2010; Brighouse and Swift 2009, 2014; Brake 2015. For the "distributive objection" to special obligations arising from relationships (including, but not only, family relationships), see Scheffler 2001. Very recently, Anca Gheaus and Colin Macleod have suggested, in independent work (Gheaus forthcoming; Macleod forthcoming), that framing the problem we face as constituting a challenge for the family is in fact misleading, since, they argue, there are no alternative adequate childrearing arrangements which do not exhibit the problem of partiality to a considerable, perhaps comparable, extent. I do not treat this interesting point here. 
As with the challenge of authority, a defense of the family that aims to meet the challenge of partiality must provide a justification both of what may and should be done to and for children in the name of parental partiality (whether and why some partiality towards children is justified), and of who may or should do certain things to and for particular children (who may or should be partial to which children). That is, a defense of the family must show both that the exercise of (some) parental partiality is legitimatethat children may be favored by a few adults in certain ways - and that it is justified that some particular adults (the children's parents) treat them, specifically, in ways that constitute or display partiality.

It is important to note here that the problem of partiality as I have just characterized it is different from another version of the problem of partiality that is commonly discussed in moral philosophy and with which the one under consideration is normally conflated. That problem points to the anti-maximizing potential of partiality, that is, the fact that partialityinclined agents fail to maximally pursue morally mandatory aims. The fact that a parent's hefty expenditure on his child's skiing trips—or indeed, any expenditure on his child at all, assuming the parent could have chosen not to have the child and hence not created the need for this use of his resources-could and should be put to supposedly morally better use by being sent to Oxfam or provide food for the starving is a case in point (Brighouse and Swift 2009: 51). This objection to partiality is as much an objection to partiality towards oneself as it is an objection to partiality towards one's children.

By contrast, the problem of partiality under consideration here, as already mentioned, points to the equality-disrupting effects of partiality; viewing partiality as problematic for this reason is compatible with upholding a non-maximizing view of the demands of morality (and of justice), and with thinking that people enjoy an agent-centered prerogative thanks to which some self-serving behavior is perfectly admissible and consistent with morality and justice. If the worry is with the equality-disrupting effects of partiality, a parent's hefty use of his rightfully held resources on skiing trips for himself is unproblematic, even if this results in an identical or even greater loss to Oxfam than would have been incurred had the parent used the money for his child. By the same token, if the worry is with the equalitydisrupting effects of partiality, an exercise of parental partiality that, for whatever reason, did not undermine equality is not problematic. A fanciful world in which all parents exercised partiality to the same extent and with the same impact on their children would not be unjust, on the view under consideration. The fact that this world is one in which partiality hinders the achievement of the best outcome is irrelevant. When discussing the problem of parental partiality, political philosophers often move from one to the 
other of these two worries (see Brighouse and Swift 2014: 144). ${ }^{3}$ However, they are importantly different.

Noting this difference helps to make apparent that, for liberal egalitarians, the challenge presented by the problem of partiality includes the objection pithily formulated by Robert Nozick against "patterned theories" of justice. Nozick said that because they condone individuals' spending of rightfully held resources on themselves, but condemn that spending of resources on others, these views are "individualism with a vengeance!" (Nozick 1974: 167). The objection seems particularly serious for those versions of liberal egalitarianism, which I am assuming here, that view some or all inequalities that result from people's choices as compatible with justice. On these theories, justice is compatible with individuals' partiality towards themselves, as manifested in choices to avail themselves of the opportunities that are equally on offer for everyone, even if these opportunities are competitive and even if the individuals in question could make choices that display less partiality towards themselves. To take a simple example: if A and B are equally talented and, at the onset of adulthood, both have the opportunity to embark on a management course that would enable them to compete for a lucrative position, they are permitted to embark on that course in order to benefit themselves. They are permitted to do so even if this comes at a cost to the other party (because there is only one position for which they will compete), and they are permitted, by justice, to reap whatever advantage their unequal choices would lead to. These "responsibility-sensitive" versions of liberal egalitarianism take "the individualism" Nozick identifies a step further than the theories Nozick targets, in that they allow not just for self-serving spending, but also for self-serving, inequality-producing investment choices. ${ }^{4}$

The asymmetrical standing which liberal egalitarianism confers on partiality to self and partiality to one's children seems questionable. Some parental partiality seems to be morally commendable, and more commendable than comparable partiality towards oneself. So, in answering the challenge of partiality, it would be desirable if the justification of the family that liberal egalitarians offer could defuse the worries raised by the Nozickian objection,

3 The claim that in a world like ours, much parenting is "the moral equivalent a tax shelter," which Scheffler (2001: 85) makes and Brighouse and Swift (2014: 25) endorse, is an illustration of this, since tax shelters hinder both inequality and the optimal pursuit of morally mandatory aims. Under realistic conditions, the two objections to partiality I distinguish here pull in the same direction, and this may explain why they are conflated: partiality disrupts both equality (and other distributive goals, such as priority for the worse off, or sufficiency) and the maximal pursuit of other morally mandatory goals.

${ }^{4}$ See Clayton 2012 for a discussion of egalitarianism and inheritance that takes Nozick's point seriously. 
and capture the way in which the parent-child relationship, at least under certain conditions, is morally valuable. In what sense exactly the family is morally valuable is of course what is in contention, and the discussion that follows will attempt to tease out a plausible interpretation of that claim. Minimally, and as a starting point, we can say that recognizing the moral status of the parent-child relationship involves two things. First, it involves recognizing that some parental partiality is morally required. Second, it involves not viewing that relationship and the disposition that characterize it as an evil (not even a necessary evil). Discussion of two competing views of the family, to which I now turn, will help bring to view more aspects of the moral status of the family.

\section{THE INSTRUMENTAL JUSTIFICATION OF THE PARENT-CHILD RELATIONSHIP}

One possible justification of the family that tries to meet the challenges of authority and of partiality is the instrumental justification. On the instrumental view, the parent-child relationship is fully justified by the fact that it serves the realization of agent-neutral values. More specifically, this view is characterized by two central claims: that the justification of the parent-child relationship lies solely in the fact that it best serves children's interests (in some versions, also third parties', or social, interests); and that the relationship serves these interests instrumentally: it is the best available means for realizing independently defined interests, i.e., the interest of children in having their needs met, or their rights respected, where these interests make no reference to the non-instrumental interest in the parent-child relationship itself.

Two different examples of the instrumental view are Robert Goodin's and Peter Vallentyne's accounts of the parent-child relationship. On Goodin's assigned responsibility model, we must ask what distribution and configuration of parental rights and responsibilities can best ensure that the needs of vulnerable children are met as well as possible (Goodin 2005). Children's needs provide the same agent-neutral reasons for everyone, and any special responsibilities that parents have are "distributed general responsibilities," which everyone retains in residual form and which are reactivated when those with special responsibilities prove unable or unwilling to discharge those responsibilities. Any rights that parents have over and vis-à-vis their children are rights that help them discharge those distributed general responsibilities.

For a view like Goodin's, showing that the justification of the parentchild relationship can meet the challenges of authority and of partiality, in 
both its role definition and identification aspects, reduces to the mostly empirical task of showing that that relationship is the best means of ensuring that we attend well to children's vulnerabilities. The reason why a few adults (independently of any particular answer to the question of who these adults are, and why they are the ones entrusted with these prerogatives and obligations) may and should exercise authority over some children and display partiality towards them (independently of any answer to the question of which children which adults should be in charge of), in ways that justify the parent-child relationship in some form, is that so doing is the best way to ensure that their needs are met, given what we know about the nature of children's needs and adults' capacities to respond to them. Similarly, the answer to the question of why some authority should be exercised and some partiality displayed by some particular adults over and towards some particular children adduces empirically grounded reasons for endorsing certain criteria for the selection of parents and for matching certain parents and certain children.

Goodin suggests here that the reason why the general responsibility to meet children's vulnerability in the context of parent-child-like relationships should be distributed so that procreators may and should care for their own children is that "responsibilities for protecting the vulnerable fall, in the first instance, to those people to whose actions and choices the child's interests are particularly vulnerable." This suggestion, in my view, is problematic. The criterion Goodin deploys for answering the question at hand seems vacuous if we assume-as I take it Goodin thinks we should assumethat whether adults who procreate should have their children become vulnerable to them in the first instance is a morally open question. So, Goodin needs some other explanation of why particular adults should acquire authority and display partiality towards particular children. Various options are open to an instrumental view like his, and which of these Goodin should favor will depend on the broader political philosophy of which the instrumental view is a part. Since Goodin endorses a consequentialist view on which all adults, including procreators, have a general positive duty, and only that general duty, to respond to children's vulnerabilities, it seems that being best able to fulfill that general duty provides a sufficient as well as necessary condition for why some adults should be parents for some particular children. The nature of the reasons why some adults are best able to discharge the general duties of everyone is irrelevant. It might be that, because genetic attachment is a motivationally efficacious drive for caring for a child, biological parents should raise their genetically related children; alternatively, or additionally, it may be that willingness to adopt the parenting role, regardless of one's genetic connection to the child or the role one has played in causing that child's existence, is a good proxy of how good a 
parent one will be. An instrumental view like Goodin's sits well with an ecumenical answer to the identification component of a defense of the family, on which begetting, genetic connection, and intentionally taking up the parenting role can all, depending on the facts, justify identifying some adults as the ones who have authority over, and partiality prerogatives towards, some particular children.

Vallentyne's account differs from Goodin's in three main respects. First, Vallentyne adopts a different view of the claims of children. Whereas Goodin resists ascribing rights to children, and conceives of their interests in light of the noncomparative standard of needs, on Vallentyne's view children have interest-protecting rights, and the interests in question have a substantial comparative component (apart from the right to personal security, which is a right to non-interference, all children, like adults, have equality rights, i.e., "rights to have their life prospects improved by others when the demands of equality so require" (Vallentyne 2003: 992)). Second, Vallentyne explicitly views maximal promotion of the child's interests as the main but not sole criterion for justifying the family; third parties' interests are also relevant. As he notes: "The benefits to the child are the main justification for childrearing rights. They are not, however, the sole considerations. The expected effect of the childrearing rights on the child's disposition to violate the rights of others is also relevant. An individual acquires childrearing rights just in case her possession of those rights... ensures that the child will respect the rights of others and suitably promotes the child's interests" (Vallentyne 2003: 996). ${ }^{5}$ Third, Vallentyne holds that although the justification of the family - of why there should be parent-child relationships, and of which adults should occupy those relationships and with which children — will be settled by considerations about what is in children's best interests (together with consideration about what is best for third parties), those considerations do not determine the content of parents' duties: "the claim is not that those who have childrearing rights have a duty to provide the best upbringing they can for the child" (Vallentyne 2003: 998). Parents' obligations, rather, are only to do better by the child's rights than other available parents and than childrearing arrangements other than the family. Here, as with Goodin's view, the facts that an adult is a child's biological parent, or that he was responsible for the child's existence, are only relevant, if they are relevant at all, because and insofar as they correlate with these adults' being both willing and better able than other adults to discharge the

${ }^{5}$ Vallentyne makes this claim with regard to the issue of who should exercise authority and display partiality vis-à-vis which child, but I assume he would want to invoke the same consideration when settling the question of whether there should be parent-child relationships at all. 
parenting role and do better by their child than if the child were not brought up in a family.

Vallentyne's account is declaredly a "radically strong child-centered conception of childrearing rights," and meets the authority and partiality challenges to the defense of the family head on. Since, on this view, the parent-child relationship is justified if and to the extent that it is the best of the available means for protecting children's and third parties' rights, justification of that relationship is ipso facto an answer to those challenges. In fact, we could say that the challenges of authority and of partiality simply evaporate if we adopt the instrumental view. But on closer inspection, the way in which the instrumental view meets those challenges is unsatisfactory, in that it fails to accommodate some intuitively defensible desiderata on how those challenges should be met. To see this, recall that, as I noted in section 1, among the various possible ways of meeting the challenge of partiality only some capture the conviction that some parental partiality is morally commendable: a justification of the family that viewed parents' disposition to be partial to their children as a wrong that is nonetheless, on balance, justifiable (because, given human nature, it is the inevitable price we must pay in order to ensure that every child's needs are satisfied) would not meet this desideratum.

Instrumental views of the family do not seem to adequately capture the family's moral status. It is true that on these views, some parental partialitythat which involves fulfilling a general duty of care, or that which involves doing better by the child's rights than alternative available arrangements-is thought to be morally required. But, as others have already remarked, instrumental justifications do not seem true to our understanding of the reasons parents have to be partial to their children (Brighouse and Swift 2009; Kolodny 2010). This is so even if we focus only on the partiality that instrumental justifications would recognize to be morally required (in that it would help realize agent-neutral values such as the value of meeting needs). The reasons parents are morally obliged to duly care for their (rather than other) children are not, or not solely, that by so doing they are contributing to a scheme that ensures that all children's needs are met as well as possible (pace Goodin), and not even that by so doing they are doing a better job than other alternative would-be parents and childcaring institutions (pace Vallentyne).

Moreover, and relatedly, instrumental justifications of the family give too flimsy a protection of the parent-child relationship, and of specific parentchild relationships (Jeske 1998; Brighouse and Swift 2009; Kolodny 2010; Macleod 2015). If children's interests could be better served by a system of well-run orphanages, or by a system of periodic reallocation of children to parents, then according to the instrumental justification, parents would 
have no reason to favor their children's rather than others' children's interests, and they would have no reason for wanting it to be the case that it is they, the parents, who help realize their children's interests by caring for them.

These claims seem to many to be too counter-intuitive to be acceptable. We could then say the following: while the instrumental justification of the family partially satisfies a first requirement of a plausible account of the family - that of capturing the family's moral status, by accounting for the fact that some parental partiality is morally required—it does not fully meet it, because it mischaracterizes the reasons parents have to exercise authority over children and to be partial to them; moreover, it does not meet a second requirement, that of giving a robust defense of the family — that is, a defense of it that does not view its value as relative and contingent in the way in which instrumental justifications do.

\section{THE RELATIONSHIP VIEW}

Partly moved by dissatisfaction with the instrumental view, some liberal egalitarians have defended a relationship view of the family. The relationship view rejects both the distinctive claims of the instrumental view-i.e., that the justification of the parent-child relationship lies solely in the fact that it best serves children's interests; and that the relationship serves these interests instrumentally. In their place, the relationship views holds that the parents' interest in the parent-child relationship also has significance in the justification of the family; and that the relationship's contribution to parents' (on some versions of the view, as well as to children's) well-being is not merely instrumental: instead, the parent-child relationship is also a constitutively valuable component of parents' (and children's) well-being.

Two main defenses of the relationship view formulated in the context of a liberal egalitarian framework are Colin Macleod's and the account developed by Harry Brighouse and Adam Swift. ${ }^{6}$ These views mostly focus on elaborating the second claim above and thereby, indirectly, provide support for the first. According to Macleod, the family is valuable in that it protects a number of valuable interests of its members. ${ }^{7}$ The close parent-child

${ }^{6}$ Brighouse and Swift 2006, 2009, 2014. The dual interest view defended by Austin (2007) presents several similarities to Brighouse and Swift's account. See also Jeske (1998) for the importance of intimacy in justifying duties of partiality in the context of relationships.

${ }^{7}$ Macleod's attention, unlike Brighouse and Swift's, is not exclusively focused on the relationship between parents and small children-he also considers the value of the family for grown up children, for other family members, and for cultural groups. I leave these points aside here. 
relationship provides the context in which children's developmental needs are met, their basic welfare is attended to, and their specific needs properly identified (Macleod 2002). These ways in which the family is valuable, it seems, identify its instrumental benefits. But the family is also non-instrumentally valuable for both parents and children in various ways: it provides them with the goods of familial intimacy (the closeness of intrinsically valuable loving relationships, in which members participate in shared activities), cherishment (the opportunity for establishing and enjoying deep emotional attachments), and expressive self-extension (the opportunity to pass on one's ideals to one's children) (Macleod 2010; see also 2002). Insofar as the family secures these fundamental goods for adults and children, liberal egalitarians have reasons to promote and protect it.

On Brighouse and Swift's view, the parent-child relationship is both instrumentally vital for the promotion of children's healthy development, and non-instrumentally valuable for adults insofar as it allows them to enjoy a particular objectively valuable good: the good of intimacy in the context of a fiduciary relationship with a child. Moreover, on this account, the instrumental and non-instrumental value of the family are closely related: the non-instrumental value of the relationship to the parent depends upon that relationship's delivering its instrumental value to the child. What is valuable for the caring adult is to be in a relationship in which she takes care of and cares for a child - a relationship which, by dint of certain characteristic features, has distinctive value, so that it is, for many people, an irreplaceable, as well as very important, source of well-being. Parents have great power to influence the child's present and future well-being, and a responsibility to exercise this power in the child's interest. By discharging their responsibilities, parents enjoy a particular type of intimate relationship with their children, one in which the children entrust and reveal themselves to their parents, with spontaneity and unconditional love, and parents, in turn, also share themselves, but also modulate display of their own love for their children so as to help them become increasingly independent. The fact that the parent-child relationship is non-instrumentally valuable for the parent, as well as instrumentally valuable for children, grounds a case for respecting and sustaining that relationship, and for helping to protect an opportunity to enjoy it for everyone.

Like the instrumental view, the relationship view can invoke the family's value for children in its response to the challenge from authority. As Brighouse and Swift emphasize, "the rights that parents have over the children they parent are... entirely a function of the interests that children have in being parented by adults with those rights" (Brighouse and Swift 2014: 74). Nonetheless, unlike the instrumental view, the interests of parents play a role here too: the relationship view holds that, provided parents are good 
enough, their interests in having an intimate relationship is weighty enough to count against their children's potential interests in having a better parent. It is worth noting that the fact that the account has this implication-the fact that it justifies the rights of parents who may be not be optimally good parents-does not mean that it is incapable of meeting the challenge of authority: defenders of the relationship view could point out that the view is best understood as an appeal to each single person's interests while a child and to his interests while an adult. Any potential trade-offs between parents' interest in being able to parent and children's interests' in having better parents is then an intra-personal trade-off, ${ }^{8}$ and one where some sacrifice in one's interests as a child is justified for the sake of securing for oneself the opportunity to establish this very important relationship as an adult.

As for the challenge of partiality, the relationship view has some resources to defuse it, in that it holds that only some equality-disrupting partiality is justified, namely, that which is integral to these valuable relationships. Reading bedtime stories for one's children is Brighouse and Swift's central case of legitimate parental partiality: here is a case of partiality that is inequality-engendering but which clearly helps realize the intimacy that is distinctive of the familiar relationship goods parents (as well as children) have an interest in enjoying. By contrast, much partiality that is standardly exercised is not necessary for realizing the valuable relationships, and stands condemned by the relationship view. For example, it is not necessary, for the realization of the value of the parent-like-relationship, that the parent bestow a large inheritance on his child; nor is it necessary that the parent engage in an inequality-engendering form of intimacy-forming activity (taking worldwide sailing trips together).

The relationship view, then, can help defuse the distributive worries that liberal egalitarians have about partiality, while at the same time providing a more robust defense of the parent-child relation than the instrumental model. Nonetheless, I think the relationship view still fails to capture the whole truth about the distinctiveness and moral credentials of the parentchild relationship, and to provide a sufficiently robust defense of it. Two points, in particular, are worth noting.

Consider, first, what obligations of parents the relationship view can account for. It does account for the moral obligations parents have to act as their children's fiduciaries, once they have embarked on that relationship with their children. But parents do not, on this view, have to enter such relationships with their children. This fact is morally significant. It is one thing to say that, although $I$ do not owe you good X (the good of being in a

${ }^{8}$ For this way of thinking of the conflicting claims of parents and children, see Clayton 2006. 
relationship with you, which includes the good of discharging certain duties I would undertake if I entered the relationship), if I choose to provide that good for you I incur certain obligations; and another to argue that I owe you that good in the first place. The relationship view can accommodate only the first claim; yet, as I argue below, the second too seems to be true in the case of parents and children.

Secondly, and relatedly, the relationship view is silent on the question of who should parent (i.e., enter the parent-child relationship with) which child. It accounts for those obligations and prerogatives that parents acquire vis-à-vis their children once they have started parenting them, or once the parent-child relationship is established. It does not, however, provide any justification of why parents have a right to establish a relationship with their children before they have had an opportunity to establish it, and where no such relationship has been established. 'What's more, the relationship view could, in fact, be deployed in favor of distributing children (before a relationship has been established) of parents who already have one child, to other adults who would be "willing, and adequately good, parents." is the sense in which I think the relationship view does not provide a fully robust defense of the parent-child relationship. In the next section, I sketch a view of the status of the parent-child relationship that aims to remedy these problems, but first I should consider two main replies that might be made on behalf of the relationship view.

First, defenders of the relationship view can try and argue that the relationship view does in fact have the resources to ground a duty, on the part of parents, to establish relationships. They can point to the fact that (prospective) parents have a general duty to ensure that children have what they need, and if what children need are relationships, then prospective parents have a duty to enter those relationships. Brighouse and Swift, like Goodin and Vallentyne, explicitly endorse this claim, holding that children have "a right to a parent" and that "adults have a duty to parent children" (Brighouse and Swift 2014: 82). In my view, this reply is unsatisfactory: that general duty

9 Kolodny raises a similar criticism of Diane Jeske's friendship view of parental partiality. See Kolodny 2010: 58. I think a similar criticism can be raised against the relationship view, a version of which he too endorses.

${ }^{10}$ Brighouse and Swift say that because of the importance of adults' interests in having children, their view could answer affirmatively the question: "Would there be anything wrong with a system that distributed children to adults in the way that maximized the realization of chlidren's interests, even if it left out some adults who would be willing, and adequately good, parents?” (Brighouse and Swift 2014: 86). But, I am suggesting, they could not answer affirmatively the question of whether there is anything wrong with a system that distributed children to childless adults who would be willing and adequately good parents, by taking them from equally willing and adequately good parents who have brought those children into existence and already have one child. 
to parent children is, as they go on to say, "best understood as the duty to play one's part in ensuring that children who need parents get them" (83), and parents (those who are morally responsible for a child's existence) do not have this duty any more than anyone else does. As I said earlier with regard to the instrumental view, this picture does not capture our convictions about the nature of the reasons that parents have. The reasons parents are obliged to enter a relationship with a child is not (or not solely) that by so doing they are doing their bit in a scheme that ensures that all children's rights are met. Moreover, the reply at hand would still not ground the claim that parents have the duty to enter a relationship with any child in particular.

Defenders of the relationship view can offer another reply which attempts to show that the relationship view has the resources to justify the assignment of some children to some parents, in particular: they can argue that an intimate parent-baby relationship can and typically does form during gestation, and that this can ground birth parents' rights to continue that relationship after the child's birth (Gheaus 2012). This argument, however, justifies only a right, and not an obligation, to establish a (post-birth) parentchild relationship, and does even that only conditionally upon an intimate bond's having been formed during gestation. Even this extended version of the relationship view, then, in my view fails to capture some important aspects of the moral nature of the parent-child relationship, which I elaborate upon in the next section. ${ }^{11}$

A second main reply that defenders of the relationship view can make is that the relationship view is merely incomplete. It provides an answer to the question of whether there should be parent-child relationships, and leaves open the question of who should parent which child. In response, I acknowledge that the relationship view is indeed incomplete and so the view I sketch in the next section could, in principle, be endorsed alongside a version of the relationship view. However, it is important, in my view, to note that the incompleteness of the relationship view of the parent-child relationship is not innocuous. Instead, as I anticipated in section 1, I believe that a justification of the parent-child relationship must tackle both questions mentioned

11 The gestation view also faces another main objection, in my view, as an argument aimed at establishing the right to raise one's biological child that protects birth parents against reallocation of babies. This is because the argument seems able to show only that adults who have children with the expectation of raising them acquire the rights to raise them, since it is certainly true of these adults that they incur costs which they see as offset by the prospect of raising that child, and that they form a bond during gestation with the child they foresee being able to raise. However, if and once a system of reallocation of children is in place, presumably adults who would choose to gestate babies would be different, and form different expectations, from those who choose to gestate children with a view to raising the children they gestate. 
above, and tackle them together. We need an account of both what may and should be done to and for children, and who may and should do certain things to and for children and for which ones in particular.

Defenders of the relationship view, like defenders of the instrumental view, assume that the first question is normatively prior to, can be answered independently from, and indeed sets the parameters for answering, the second. ${ }^{12}$ But this assumption, which no one ever argues for, seems to me to be unwarranted. Our answer to either of these two questions can be affected by our answer to the other. Sure enough, what may and should be done to and for children can affect the answer we give to the question of who is eligible to be a parent, and in virtue of what, and for which child. But our views about who should parent which child, and why, can in turn affect our views about what the parent-child relationship may and should deliver for both adults and children. By way of illustration, consider how our views about what friends may and should do for one another would be affected if it were the case that most or all people who enter friendships are responsible for causing their prospective friends' need for a friendship. If such a fact were true, we would not think that we can settle the question of what friends owe to one another prior to, and independently from, considerations about who should be friends with whom.

\section{PARENTS' OBLIGATIONS TO ENTER A PARENT-CHILD RELATIONSHIP}

The two concerns about the relationship view I have just raised, I now suggest, reflect a tendency to overlook an important way in which the parent-child relationship differs from other relationships that, alongside this one, are often thought to be the site of prerogatives and/or special obligations. Unlike those other relationships (such as friendship, or the relationship between loving companions, or that between compatriots), the parent-child relationship is one that some individuals - the children's parents—have a special obligation to enter. In turn, neglect of this aspect of the parent-child relationship reflects a general tendency on the part of philosophers, rightly identified and criticized by Margaret Little, to adopt too narrow a view of the ethics of relationships. As she remarks: "In ethics, if we notice relationships at all, we tend to focus only on questions about what morally flows

12 Brighouse and Swift, for example, say that their focus is on whether "there should be parents at all" and note: "It is, on our account, a separate and further question which adults should parent which children" (Brighouse and Swift 2014: 49, emphasis in the original). 
from or governs relationships once they have been entered.... But there is another layer to the ethics of relationships: considerations surrounding whether one ought to enter-or be open to entering — a relationship, and again, whether it is permissible to exit it" (Little 1999: 307).

My central claim in this section is the following: parents-those who are morally responsible for causing someone's existence-in standard cases have a right to raise their children, grounded in an obligation to the person(s) whose existence they are morally responsible for to establish a parent-child relationship with them. Whereas the relationship view focuses on the obligations that are generated by the parent-child relationship, the duty I am drawing attention to is a duty to generate that relationship. In what follows I unfold this claim in three steps, by first explaining in what sense children need relationships, then motivating the idea that parents have an obligation to enter a relationship with their children, and finally, by clarifying the idea of what makes someone responsible for a child's existence in the relevant sense.

Before turning to that, I should clarify at the outset that my claim is that parents have this obligation to their children; a natural alternative candidate claim is that they have this obligation to third parties. ${ }^{13}$ We might think that, unless parents provide for their children, they are imposing negative externalities on non-consenting others (both society at large for having to incur many of the costs of raising and maintaining these children, and perhaps also for those individuals who would take it upon themselves to step in and discharge the parenting role). We might think, furthermore, that, if and since parents are responsible for doing so, this would be unfair to third parties. I do not think it is true in general that if, by having and rearing children, parents create costs for others, this is necessarily unfair for these others. But what I say in what follows is compatible with either accepting or denying that parents have an obligation to a class of specified non-consenting third parties (their other family members, their fellow citizens) to provide due care to their children themselves. Let me now turn to the claims I do want to defend.

To be morally responsible for a child's existence is not only to create a vulnerable creature: it is also to create a vulnerability of a particular kind,

13 John Stuart Mill, for example, thought that "to bring a child into existence without a fair prospect of being able, not only to provide food for its body, but instruction and training for its mind, is a moral crime, both against the unfortunate offspring and against society; and that if the parent does not fulfil this obligation, the State ought to see it fulfilled, at the charge, as far as possible, of the parent" (Mill 1978: 104; emphasis mine). For the claim that, provided that there are willing adoptive parents, those who bring children into the world but are unwilling to rear them themselves do not act impermissibly, see Archard 2010b. 
due to the fact that virtually all of an infant's needs, and many of a young child's ones, both immediate and developmental, have a strong relational component. By saying that needs have a strong relational component, I mean that the adequate (and certainly the maximal) satisfaction of these needs requires that they be met in the context of a relationship, and more specifically, of an ongoing, stable relationship with one or few caring adult persons (see, for example, Gerhardt 2004). Given what we know, in order to fare well as children, and in order to become well-functioning adults who have a full opportunity to flourish, children need to be in a parent-child-like relationship: their care needs to be dispensed for them in the context of a close bond with loving adults.

So, to say that a new child has needs that must be satisfied for her to fare well, and that she is herself incapable of satisfying, as the instrumental view says, is an assertion that, while not false, under-describes the situation of a child in ways that are morally significant. To see this, consider the case of an adult person who is unable to walk or to dress herself: she has some important basic needs (to move about; to change her clothes) that she is unable to meet herself. In order to have them met, she may need another person or persons to step in to help. But these needs are not relational: they can be adequately, even maximally, satisfied by having a person or various persons one is not in a relationship with step in to discharge the specific tasks. This needy adult may be better served, in fact, by having a dependable wheelchair and, if such a device could be invented, one that changed her clothes. The neediness of children is importantly different from the neediness of adults. ${ }^{14}$

My second claim is that not all adults, not even all adults who would be willing and competent to enter a relationship with a child, stand equally placed, morally speaking, vis-à-vis the child's relational needs. This is not only or even primarily because, by bearing moral responsibility for the child's being needy of a relationship, they now owe it to the child to ensure that the child's need for a relationship is met so as to avoid being the cause of harm to the child, as a tort model of parental obligations would hold (more about that later). Rather, by dint of being morally responsible for a child's existence, the parents now stand in a position such that their entering a relationship with the child, or not entering it, expresses something different from what other adults' entering or not entering that relationship expresses.

${ }^{14}$ Is it just that they are not yet autonomous and their dependency is not an affront to their status? This is certainly part of it. But it also seems important that the child is being trained to become an adult and a moral agent, and that we can only develop these skills and competencies in the context of relationships. 
So, even saying that the child's need is for a relationship, as the relationship view fully acknowledges, seems to importantly under-describe the situation in ways that are morally significant. To illustrate: if my friend is in hospital and, knowing she would be cheered up by a friend's visit, I proceed to call up another friend of hers and arrange for him to visit my hospitalized friend, although I lack a good reason for not going to hospital myself, my setting up this arrangement expresses something different than would be expressed by a nice nurse who performed the same action, even though we are both responding to the hospitalized friend's need for a friend's visit. ${ }^{15}$ What an action expresses can change in line with the nature of the relationship in the context of which it takes place, as the example just mentioned illustrates. But it can also change in line with the role that the person who performs the action played in creating the need for that action: a hospital visit from the stranger who is responsible for the accident that led to my friend's hospitalization is importantly different from that of another stranger who just witnessed the accident's taking place. Similarly, I am suggesting, if someone knowingly and voluntarily causes someone to be needy of a relationship, her refusal to be a party to it can be plausibly viewed as a rejection of the needy person. Their responding to that person's relational neediness by entering the relationship themselves, or by ensuring that someone else enters the relationship, are not two morally equivalent ways of discharging the same obligation. Since for most children there are parents who are morally responsible for having brought them into existence, the parent-child relationship under conditions we are familiar with is different from other relationships, including valuable relationships in the context of which special obligations are often said to arise, such as friendship. We do not standardly have any obligation to a particular person to become their friend, even if that person is needy of a friendship, though there may well be general duties to help provide everyone with the opportunity to have valuable relationships.

So far I have talked about parents as those who are morally responsible for a child's existence, without specifying what conditions are necessary and sufficient for moral responsibility. It is important to say something about these conditions, because in my view their being what I think they are plays a role in support of the claim that parents' entering, or failing to enter, into a relationship with their children carries a special meaning. Like with ascriptions of responsibility for other actions, causal responsibility for someone's existence is a necessary but not sufficient condition for being morally responsible for it. Besides causal responsibility, it is also necessary that the

${ }^{15}$ On the expressive meaning of actions, see Sunstein 1995/6; Anderson and Pildes 1999/2000. See also Khaitan 2012. 
parent voluntarily brings that child into existence, where voluntarily bringing into existence means that the parent knowingly brings that child into existence, and does not choose to bring the child into existence only or primarily because she has no alternative to it, or only because the alternative is unacceptable, prudentially or morally. This, in turn, means that standardly, the conditions for being morally responsible for a child's existence are that the child's existence was avoidable, i.e., it would have been possible, prudentially acceptable, and morally permissible for the parent not to bring the child into existence. ${ }^{16}$

Together, these conditions can be sufficient. I say that they can be sufficient to allow for the fact that when someone voluntarily and avoidably brings into existence a child on someone else's behalf, moral responsibility for that child's existence lies with the latter person. This point is important, because it shows that my view does not imply that gamete donation and surrogacy are morally impermissible: as far as moral responsibility for existence is concerned, and insofar as there are commissioning parents who are morally responsible for the existence of the children who are genetically derived from donated gametes and gestated by surrogate mothers, gamete donors and surrogates are in a position that is quite like that of an IVF doctor whose intervention is causally decisive both in starting a pregnancy and in carrying it to term. By contrast, their position is importantly unlike that of a parent who, though morally responsible for a child's existence, decides to give up his child up for adoption. The claim that gamete donors and surrogate mothers, like IVF doctors, can be seen to be acting on the commissioning parents' behalf implies that, instead of thinking of gamete donors as transferring parental responsibilities, as is often done (e.g., Benatar 1999; Bayne 2003), they should be thought of as not acquiring those responsibilities at all in the first place. This is compatible with thinking that they do have some responsibilities. However, in the absence of a warranted and justified intention to enable other individuals to bring a child into existence, those who voluntarily cause that child's existence are morally responsible for it, and have an obligation to enter a parent-child relation with her. (Similarly, voluntarily signing a contract binds the person who signs it, unless she is signing on behalf of a party who has so authorized her.)

16 I say "standardly" because, on my view, what matters for voluntariness as a condition for substantive responsibility are the motivating reasons why someone chooses as she does, and it is possible that lack of an acceptable alternative does not motivate someone to choose as she does (e.g., someone could choose voluntarily to have a baby even if, if she did not have one, she would face real danger, provided that her reasons for having a baby are not only or primarily that she wants to escape danger). See Olsaretti (2016) for further elaboration and defense of this account of voluntariness. 
The fact that moral responsibility for someone's existence requires more than causal responsibility helps lend some plausibility to my claim that that moral responsibility grounds an obligation to parent. This is so for two reasons. First, intuitively, mere causal responsibility on its own seems too weak to ground an obligation of the kind I am defending here, although it may ground other obligations (see Brake 2010. I return to this point below). If someone causes a child to exist, but was forced to do so, holding her to the obligation to raise that child, rather than to the obligation of ensuring that that child is parented by someone else, may strike us as too demanding on the procreator. This objection does not bite, however, if the procreator voluntarily brought the child into existence. Second, the fact that moral responsibility for existence requires these further conditions helps account for why parents have the obligation I ascribe to them. The fact that parents are those who voluntarily bring someone into existence- the fact, in other words, that the child's existence was up to the parents' choice in an important sense-is what makes it the case that not entering a relationship with this child would be disrespectful.

At the start of this section, I suggested that those who are morally responsible for causing someone's existence in standard cases have a right to raise their children, grounded in the obligation they owe their children. I should now unpack what I mean by "standard cases." These are the range of cases where parents are able and willing to discharge that obligation to their children sufficiently well. My claim is not that the fact of parents' obligations to enter into a relationship with their children invariably grounds a right to enter into those relationships. Whether or not it does depends on whether parents are able and willing to fulfill that obligation, that is, whether they are able and disposed to establish and maintain a caring parent-child relationship with their child, which involves meeting the child's needs in the context of that relationship. ${ }^{17}$ If the parent is either unable or

${ }^{17}$ In the case in which parents voluntarily bring a child into existence with no intention to care for the child, or in which they come to lack that intention once the child exists, they are clearly in violation of the obligation and acquire no right to care for the child. But what about cases where they are unable to enter that relationship? There are relevantly different cases here, depending on whether the parents' inability preceded their choosing to create a child, whether they are responsible for it, whether or not it is remediable, and on the role that the fact of the inability plays in the parents' deliberations. Consider the case of a parent who, after conceiving a child, is struck by unforeseen misfortune which she cannot remedy, and, although she would like to raise the child herself and would be willing to take measures to remedy this if any were available, is aware that her child will suffer if she keeps him and gives him up for adoption. This parent is arguably not in violation of the obligation, as nothing in her decisions and actions evinces an attitude of disrespect for the child's value. By contrast, someone who, aware that he will not be able to care for a child, nonetheless proceeds to have one, and/or whose inability to enter that relationship is remediable but who does not take action to remedy it, does 
unwilling to meet her obligation, he has of course no right to be allowed to discharge it, though the fact that he has an obligation which remains unfulfilled is important: it remains true, of this parent, that he is wronging his child.

By way of conclusion, it will be helpful to clarify how my view differs from some main alternative views of parenthood, or views of what grounds parental rights and/or obligations to which it bears some resemblance and which I have mentioned in passing: these are, first, the view that being responsible for existence amounts to imposing an unchosen risk of harm which merits compensation; second, the intentional or voluntarist account of parenthood; and third, the view that genetic ties matter.

Consider, first, the causal view that those who are causally responsible for someone's existence have duties, to that person, to eliminate or reduce the risk of harm to her that they have unilaterally imposed on her by bringing her into existence. This view, which in its most explicit statement is defended by Nelson (1991), makes two claims: that bringing into existence harms, or imposes risk of harm, on the person who comes into existence; and that those who bring into existence in the relevant sense (that is, those who are morally responsible for existence) are those who are causally responsible for it. ${ }^{18} \mathrm{~A}$ forceful defense of the first claim is offered by Seana Shiffrin (1999), according to whom procreators engage in a "morally equivocal" activity, because no procreator can ever ensure that his child's life will not be marked by substantial suffering, and because even the most successful lives involve some such suffering. Since to procreate is to impose a risk of harm on someone, without their consent, where doing so is not necessary to save them from greater harm, and harming of this kind is wrong, procreators owe their children compensation as a result. The second claim, that those who bear causal responsibility for existence count as a child's procreator in the relevant sense (i.e., in the sense that that child's existence is justifiably attributable to them in a way that justifies considering them under the

seem to be in violation of the obligation to the child. A harder case may seem that of a parent who brings a child into the world with the intention of raising him, is capable of providing him with a decent start in life, but then decides that she should, for her child's best interests, surrender him to another family with whom, she is certain, her child will fare better. About cases like this one I would say that the parent has indeed violated an obligation she has to the child (the child would, if or when he becomes aware of this fact, still have reason to feel he was rejected), although she may be excusable if she acts in good faith. That she had an obligation (which she violated) is confirmed by the fact that we think she should make reasonable efforts to improve her own ability as a parent. We can say here some of the same things we would say about parents giving up their children once they have started caring for them, and of friends giving each other up for the sake of the friend's interest in finding a better friend.

${ }^{18}$ I here refer to the causal view as the conjunct of both these claims; only Nelson explicitly defends both of them, while several other people, including those I mention in what follows, defend only one of them. 
obligations that procreators have), is defended, among others, by O'Neill (1979), Archard (2010b), and Porter (2012; 2014).

My view differs from the causal view just sketched in three key respects. First, on my view, as I said earlier, causal responsibility is not enough for moral responsibility for existence. Second, my view does not affirm (or deny) that parents impose risks of harm or harm on their children by bringing them into existence. Finally, while the causal view can account for the special obligations parents have towards their children, it is not clear that it can account for why parents have to discharge those obligations by caring for their children themselves. ${ }^{19}$ Indeed, it seems that the duty to compensate a child for harming him by bringing him into existence generates a derivative duty to place that child in circumstances that minimize the risk of harms that she will be exposed to, which could mean that parents should give up their children at birth.

My view also differs from the voluntarist conception of parenthood, the accounts of parenthood on which a necessary and/or sufficient condition for acquiring the rights and obligations of parenthood is the voluntary acceptance of the parental role (O’Neill 1979; Brake 2010). Moral responsibility for existence is different from, and neither necessary nor sufficient for, the voluntary acceptance of the parental role. Moral responsibility, on my view, is enough to ground the obligation to enter the parent-child relationship, and indeed is what gives some prospective custodial parentsthose who were responsible for a child's existence-reason to take up the parental role. By saying that moral responsibility for existence is sufficient to ground an obligation to enter the parent-child relationship I do not mean to deny that intentionally choosing to parent, if one is capable of doing so and if a child is "available" to be parented, can also be sufficient to ground parental rights and responsibilities. Adoptive parents meet these conditions, and a version of the intentional account, on which acceptance of the parenting role is sufficient for undertaking parental obligations, is compatible with my view. Note, moreover, that nothing I have said suggests that adoptive parenthood is in any way less valuable than non-adoptive parenthood. My claim is only that non-adoptive parents-who may include the parents who have "commissioned" a child through surrogacy—have a further responsibility

19 Thanks to Andrew Williams for drawing this point to my attention with regard to Shiffrin's view. O'Neill and Archard say explicitly that they think that those who are causally responsible for existence only owe it to their children to ensure that someone discharges the parenting role vis-à-vis them. Porter's view, to which mine comes closest, does affirm that "makers" (on her view, those who are causally responsible for existence) have an obligation to enter a relationship with their children, but does not offer an argument as to why they have that obligation, rather than merely an obligation to ensure that their children are well cared for. 
when compared with adoptive parents: they are morally responsible for the child's existence, in a way in which standardly adoptive parents are not, and they have, for the reasons I sketched earlier, an obligation to enter into a parent-child relationship with the particular child for whose existence they are morally responsible.

My view also differs, finally, from genetic accounts of what grounds parental rights and obligations (see Velleman 2005, 2008; for discussion of Velleman's view, see Haslanger 2009 and Kolodny 2010; for discussion of the biological account more generally, see Austin 2004). Genetic connectedness is neither a necessary nor a sufficient condition of being morally responsible for someone's existence. A couple who decide to have a child thanks to donated gametes and a surrogate mother, for example, are responsible for that child's existence, even though they have no genetic or gestational connection to the child. In this same case, the child's genetic and gestational parents are not those morally responsible for that child's existence. Note that to say that genetic connectedness is neither a necessary nor a sufficient condition for being morally responsible for a child's existence, and hence, for the obligation to enter a relationship with that child, is not to say that it lacks all normative significance. For example, it seems plausible to think that it is a sufficient condition for some obligations, such as the obligation to provide the child (and his guardians) with relevant information about his biological family history.

I cannot here engage with the merits of the genetic view, but would like to conclude with a tentative suggestion. Although genetic connectedness and moral responsibility for existence are different and can pull apart, the former has, until recently, been a practically necessary condition for the latter, and it is still the case that, typically, genetic parents are also those who are morally responsible for a child's existence. I think it is a virtue of the view of parental responsibility I have sketched that it can explain the intuitions we have in many cases in which genetic connectedness is at work, without appealing to the moral relevance of genetic ties, and where what does the requisite work in grounding someone's obligation to enter a parent-relationship is the fact that he voluntarily chose to bring that person into existence.

\section{Acknowledgments}

Previous versions of this paper were presented at the Conference on "Family Ethics: Partiality Revisited" in Bern in January 2014, at the Oxford Studies in Political Philosophy in Missouri in September 2014, and at the graduate conference in Legal and Political Philosophy at the Universitat Pompeu Fabra in September 2015. I am grateful to all members of the audiences, and Richard Arneson, Paul Bou-Habib, 
Anca Gheaus, Colin Macleod, and Nina Scherrer for their comments. This project has received funding from the European Research Council (ERC) under the European Union's Horizon 2020 Research and Innovation Programme (Grant Agreement Number: 648610).

\section{References}

Anderson, E., and Pildes, R. 1999/2000. Expressive Theories of Law: A General Statement. University of Pennsylvania Law Review 148: 1503-75.

Archard, D. 2010a. The Family: A Liberal Defence. Basingstoke and New York: Palgrave McMillan.

Archard, D. 2010b. The Obligations and Responsibilities of Parenthood. In D. Archard and D. Benatar (eds.) Parenthood and Procreation. Oxford: Oxford University Press.

Austin, M. 2004. The Failure of Biological Accounts of Parenthood. Journal of Value Enquiry 38: 499-510.

Austin, M. 2007. Fundamental Interests and Parental Rights. International Philosophical Quarterly 47, 2: 221-36.

Bayne, T. 2003. Gamete Donation and Parental Responsibility. Journal of Applied Philosophy 20, 1: 77-87.

Benatar, D. 1999. The Unbearable Lightness of Bringing into Being. Journal of Applied Philosophy 16, 2: 173-80.

Brake, E. 2010. Willing Parents: A Voluntarist Account of Parental Role Obligations. In D. Archard and D. Benatar (eds.) Parenthood and Procreation. Oxford: Oxford University Press.

Brake, E. 2015. Creation Theory: Do Genetic Ties Matter? In S. Hannan, S. Brennan, and R. Vernon (eds.) Permissible Progeny. Oxford: Oxford University Press.

Brennan, S., and Noggle, R. 1997. The Moral Status of Children: Children's Rights, Parents' Rights, and Family Justice. Social Theory \& Practice 23, 1: 1-26.

Brighouse, H., and Swift, A. 2006. Parents' Rights and the Value of the Family. Ethics 117, 1: 80-108.

Brighouse, H., and Swift, A. 2009. Legitimate Parental Partiality. Philosophy \& Public Affairs 37, 1: 43-80.

Brighouse, H., and Swift, A. 2014. Family Values: The Ethics of Parent-Child Relationships. Princeton and Oxford: Princeton University Press.

Clayton, M. 2006. Justice and Legitimacy in Upbringing. Oxford: Oxford University Press.

Clayton, M. 2012. Equal Inheritance: An Anti-Perfectionist View. In G. Erreygers and J. Cunliffe (eds.) Inherited Wealth, Justice and Equality. London: Routledge.

Feinberg, J. 1994. The Child's Right to an Open Future. In J. Feinberg, Freedom and Fulfillment. Princeton: Princeton University Press.

Fishkin, J. 1983. Justice, Equal Opportunity, and the Family. New Haven: Yale University Press.

Gerhardt, S. 2004. Why Love Matters: How Affection Shapes a Baby's Brain. New York: Brunner-Routledge. 
Gheaus, A. 2012. The Right to Parent One's Biological Baby. The Journal of Political Philosophy 20, 4: 432-55.

Gheaus, A. forthcoming. What Abolishing the Family Would Not Do. Critical Review of International Political and Social Philosophy.

Goodin, R. 2005. Responsibilities for Children's Well-Being. In M. Prior and S. Richardson (eds.) No Time to Lose: The Wellbeing of Australia's Children. Melbourne: Melbourne University Press.

Haslanger, S. 2009. Family, Ancestry and Self: What Is the Moral Significance of Biological Ties? Adoption and Culture 2, 1.

Khaitan, T. 2012. Dignity as an Expressive Norm. Oxford Journal of Legal Studies 32, 1: 1-19.

Kolodny, N. 2010. Which Relationships Justify Partiality? The Case of Parents and Children. Philosophy and Public Affairs 38, 1: 37-75.

Jeske, D. 1998. Families, Friends and Special Obligations. Canadian Journal of Philosophy 28, 1: 527-55.

Little, M. 1999. Abortion, Intimacy, and the Duty to Gestate. Ethical Theory and Moral Practice 2, 3: 295-312.

Macleod, C. 2002. Liberal Equality and the Affective Family. In D. Archard and C. Macleod (eds.) The Moral and Political Status of Children. Oxford: Oxford University Press.

Macleod, C. 2010. Parental Responsibilities in an Unjust World. In D. Archard and D. Benatar (eds.) Parenthood and Procreation. Oxford: Oxford University Press.

Macleod, C. 2015. Parental Competency and the Right to Parent. In S. Hannan, S. Brennan, and R. Vernon (eds.) Permissible Progeny. Oxford: Oxford University Press.

Macleod, C. forthcoming. Equality and Family Values: Conflict or Harmony? Critical Review of International Political and Social Philosophy.

Mill, J. S. 1978. On Liberty. Indianopolis: Hackett Publishing Company, Inc.

Nelson, J. L. 1991. Parental Obligations and the Ethics of Surrogacy: A Causal Perspective. Public Affairs Quarterly 5, 1: 49-61.

Nozick, R. 1974. Anarchy, State and Utopia. Oxford: Blackwell.

Olsaretti, S. 2016. Voluntariness, Coercion, Self-Ownership. In D. Schmidtz (ed.) The Oxford Handbook of Freedom. Oxford: Oxford University Press.

O’Neill, O. 1979. Begetting, Bearing, and Rearing. In O. O'Neill and W. Ruddick (eds.) Having Children: Philosophical and Legal Reflections on Parenthood. New York: Oxford University Press.

Porter, L. 2012. Adoption Is Not Abortion-Lite. Journal of Applied Philosophy 29, 1: 63-78.

Porter, L. 2014. Why and How to Prefer a Causal Account of Parenthood. Journal of Social Philosophy 45, 2: 182-202.

Rawls, J. 1971. A Theory of Justice. Oxford: Oxford University Press.

Scheffler, S. 2001. Boundaries and Allegiances: Problems of Justice and Responsibility in Liberal Thought. Oxford: Oxford University Press.

Shiffrin, S. 1999. Wrongful Life, Procreative Responsibility, and the Significance of Harm. Legal Theory 5: 117-48. 
Sunstein, C. 1995/6. On the Expressive Function of Law. University of Pennsylvania Law Review 144: 2021-53.

Vallentyne, P. 2003. Rights and Duties of Childbearing. William and Mary Bill of Rights Journal 11, 3: 991-1009.

Velleman, D. 2005. Family History. Philosophical Papers 34: 357-78.

Velleman, D. 2008. Persons in Prospect. Philosophy and Public Affairs 36: 245-66. 